\title{
Entrepreneurship attitude of managers, member participation, and cooperative performance: Evidence from Indonesia
}

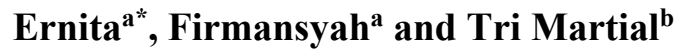

${ }^{a}$ Universitas Muslim Nusantara Al-Washliyah, Indonesia

${ }^{b}$ Universitas Islam Sumatera Utara, Indonesia

\section{CH R O N I C L E}

\section{Article history:}

Received: October 14, 2019

Received in revised format:

November 292019

Accepted: January 9, 2020

Available online:

January 9,2020

Keywords:

Attitude

Cooperative

Entrepreneurship

Member participation

Motivation

\section{A B S T R A C T}

The purpose of this study is to know the effect of entrepreneurship attitude of manager of cooperatives and member motivation in enhancing member participation in North Sumatera Province, Indonesia. A questionnaire with a 1-5 Likert's scale is used to examine the hypotheses of the survey. Respondents consisted of 100 leader/managers and 100 members of the cooperatives. The results show that entrepreneurship attitude of manager and member motivations correlated significantly in increasing the participation of cooperative members with $\mathrm{r}_{1}=0.866^{* *}$ and $\mathrm{r}_{2}=$ $0.902^{* *}$, respectively. Likewise, entrepreneurship attitude of manager and member motivation had significant effects on increasing member participation. It is also found that $\mathrm{R}^{2}=0.836$, and $\mathrm{F}$-value was 247.430 with $\alpha<1 \%$. In conclusion, the independent variable significantly correlated and increased participation of the members. It is very important to insert entrepreneurship attitude and motivation in providing cooperative education.

\section{Introduction}

Cooperative organizations in Indonesia are regarded as one of the largest civil society organizations, as well as social enterprises with great potential in rural development and job creation. Cooperation plays an important role in economic and social development, particularly in rural community development throughout the world, including Indonesia. It is estimated that 50 percent of global agricultural products are marketed through cooperative organizations. Cooperation are present in all countries and all sectors, including agriculture, food, health care, finance, marketing, insurance and credit. It is estimated that one billion people are members of cooperative organizations around the world, generating over 100 million jobs worldwide. In agriculture, forestry, fisheries and livestock, members participate in production activities, revenue-sharing, cost-savings, risk-sharing, and income-generating activities, leading to better bargaining power for members as buyers and sellers in the market. Indonesia is a developing country and around half the population live in rural areas. In 2019 the total population of Indonesia (the fourth most populous country in the world) was around 269 million people (http://www.worldometers.info/world-population/population-by-country/). This means that around 134.50 million people live in rural areas. There are around 126,343 active cooperative units as of December 2018 with a total of 20.05 million members (Ministry of Cooperatives and SMEs of the Republic of Indonesia, 2018). About 70 percent of these cooperatives are located in rural areas. The cooperative movement in Indonesia is one of the civil society organizations and is the largest social enterprise that has a large potential in rural development and job creation. Levi and Pellegrin-Rescia (1997) state that cooperatives are the only form of business with a very clear entrepreneurial component in which subordination from economy

* Corresponding author. Tel.: +81396988944

E-mail address: ernita@umnaw.ac.id (Ernita) 
to social is logical in the organization and determined by law. Unfortunately, the rapid growth of the quantity of cooperatives in Indonesia is not matched by the increasing participation of members. Participation of members in Indonesian cooperatives is still low (Riswan et al., 2017) and their awareness to participate both professionally and actively is still below the expectations of the government. Taiwo (2011, 2015); Ernita, et al., (2014ab, 2015, 2016); and Hadayati et al. (2016), show that member participation is vital in improving cooperative performance. This means that if the participation of members is not repaired then automatically cooperative performance will be low.

Ahmed and McQuaid (2005) state that successful management in this era of globalization requires developing method and approach to suit the challenge and opportunity is an entrepreneurship approach. For this reason, efforts need to be made to improve the performance of cooperative managers that lead to entrepreneurial attitudes in managing and maintaining cooperatives. The manager of the cooperative is a person whose job is to assist the management in managing, organizing and running the work and functions of the cooperative in order to run properly and perfectly so that the members' active participation can continue to increase. Hanel (2005) and Munkner (2013: 23) show that member participation is a major factor underlying the success of cooperatives. To increase the participation of cooperative members, the Indonesian government should focus on improving the quality of managers' performance by enhancing the entrepreneurship attitude, which is expected to improve their professionalism. Acs and Audretsch (2010) believe that the existence of entrepreneurs has a positive impact on economic growth because they will offer wide employment opportunities. Through entrepreneurship new sources of supply can be found and the creation of new business organizations that directly affect the economy. The creation of new business opportunities through entrepreneurship, productivity and innovation shows an increase in the direction of economic growth. This means that when there is more increase in entrepreneurship in an economy, more economic growth is expected.

Gradually, entrepreneurs are recognized as important drivers of economic development, productivity, driving forces in innovation and work, and recognized as important aspects of economic power. We find that entrepreneurial activities carried out by new entrepreneurs and young business owners / managers have influenced economic growth. Andersson and Noseleit (2011) state that entrepreneurship is a very important component in the process of reallocation of efficiency because new businesses enter the market to challenge established companies, products, and production and distribution methods; they bring something new or better and in the process of doing so, their emergence promotes a more competitive environment.

We find that entrepreneurial activities carried out by newborn entrepreneurs and young business owners / managers have influenced economic growth, but this influence depends on the level of income per capita. This shows that entrepreneurship plays a different role in countries with various stages of economic development. Fotoohi (2014) points out that many cooperatives not only continue to exist, but seem to be more successful than their competitors and can continue to offer goods and services to their members. Case studies show that cooperative entrepreneurs and entrepreneurship and new management methods play a major role in such cooperatives. According to Harun and Mahmood (2012), a new perspective on the cooperative movement where strong member relations have been able to contribute further to the growth of the cooperative movement's performance. The level of cohesiveness among members has determined the success of cooperative performance to move towards the future. Chareonwongsak (2017) shows that motivation of cooperative board of directors and manager significantly affects cooperative performance.

Based on the above phenomenon, this research investigates the influence of entrepreneurship attitude from managers of cooperative and member motivation to increase member participation as a key for the success of cooperative in North Sumatera, Indonesia. Based on the above problem, the aim of the research is to know the influence and correlation between the entrepreneurship attitude of the cooperative leader/manager and member motivation towards member participation as the key to success in the cooperative.

\section{Literature review and hypotheses development}

\subsection{Member Participation}

Participation is the involvement of a person both mentally and emotionally to contribute to the achievement of group goals and to be responsible. Increasing such participation needs to increase self-esteem, which in turn encourages mutual respect. Participation is one way to motivate. This is due to the participation of more emphasis on psychology in terms of materials, which means to involve someone and become responsible. According to Allport (1945), an accompanying person actually experiences the self and nature of ego involvement, rather than involvement in work or duty.

Given his involvement it also means involvement of thoughts and feelings. Members can be seen as the most vital part of a cooperative. It is said that members of loyal attitudes and loyal behavior play an important role in increasing the effectiveness and strengthening of cooperatives (Verhees et al., 2015; Mahazril et al., 2012; Regts, 2009). To build and maintain a cooperative as a competitor to other companies in the commercial world, members of investors must utilize all types of cooperatives with loyal customers of cooperatives. In addition, loyal customers also play a key role in the decision-making process, to determine the program and strategy of cooperative development into the future. Further, he said that the member 
participation plays an essential role in overseeing business, venture capital and enjoying benefits, and participation in evaluating the decisions of cooperative activities.

According to Allport (1945), a person who participates in the particular community should experience both self-involvement and ego-involvement. In other words, if a person participates in a particular community, he must engage his thoughts, emotions, and feelings. Hanel (2005) points out the participation of members of cooperatives relating to identity;

a. Owner. Members shall participate in decision-making, evaluation, and monitoring held in regular member meetings.

b. Owner. Members must participate in capital contributions through various cooperative deposits.

c. Owner. Members must be willing to take any risks occured.

d. Users / customers / employees. Members who have the opportunity to benefit from services provided by the cooperative.

In addition, according to Ropke (2003) participation is divided into three types, namely;

a. Participation of natural resource contributions.

b. Participation in decision making

c. Participation enjoys the benefits.

\subsection{Motivation Theory}

McClelland (1997; 2011) points out that we have all three types of motivation regardless of age, gender, race, or culture. The kind of motivation in which each individual is driven comes from his/her life experiences and opinions of his/her culture. The McClelland's of Need for Achievement (N-Ach) theory, sometimes the Three Needs Theory or Acquired Needs Theory is one of those theories that focuses on human motivation. The theory follows earlier work published by psychologist. This is based on the fact that motivation is influenced by three types of needs:

\section{Need for achievement}

They prefer to work on tasks with moderate difficulty, prefer to work where the outcome is based on their efforts rather than on other things, and prefer to receive feedback on their work. Individual-based achievements tend to avoid high-risk situations and low-risk. Low-risk situations are seen as too easy to apply and high-risk situations are seen more based on the luck of the situation than the achievements made by individuals. This personality type is motivated by workplace attitudes and job hierarchy with promotional positions.

\section{Need for affiliation}

People who have a need for affiliates prefer to spend time creating and maintaining social relationships, enjoy being part of a group, and have a desire to feel loved and accepted. People in this group tend to abide by cultural norms in the workplace and usually do not change workplace norms for fear of rejection. This person loves collaboration in competition and does not like situations with high risk or high uncertainty. People who have a need for affiliates work well in areas based on social interactions such as customer service or client interaction positions.

\section{Need for power}

People in this category enjoy work and place a high value on discipline. The downside to this motivational type is that group goals can become zero-sum in nature, that is, for one person to win, another must lose. However, this can be positively applied to help accomplish group goals and to help others in the group feel competent about their work. A person motivated by this need enjoys status recognition, winning arguments, competition, and influencing others. With this motivational type comes a need for personal prestige, and a constant need for a better personal status.

\subsection{Entrepreneurship Attitude}

According to Calhoun and Joan (1995: 315), attitude is a feeling, and or a belief in a particular object, and there is a tendency to act against objects in a certain way. Human attitude is not an innate ability, but it is something learned. So, the attitude is easily built, influenced and changed. This means that the attitude comes from a stimulus that is influenced by several factors, such as personality, environment and learning process. If a positive stimulus, a good attitude will be built, while negative stimulus will build a bad attitude. Ajzen and Fishbein (1980) and Ajzen (2011), point out the theory of reasoned action that explains the relationship between attitudes and behavior. It describes the decision to show a certain attitude that takes a long rational process and is also built from the order of thought. In other words, building behavior begins with a choice of attitude, then all shadows are evaluated, the final decision that makes whether to do or not. In short, the decision is a reflection of behavior. Based on that theory, there are two factors that affect one's intention in doing something; first, evaluate a positive or negative attitude; second, consider subjective norms or people's perceptions of whether the behavior is accepted or not. In other words, the more positive the attitude toward an object, the more positive consequences it receives. In addition, the more 
subjective norms, the greater the intention to perform good behavior. In short, the theory of reasoned action is illustrated in Fig. 1.

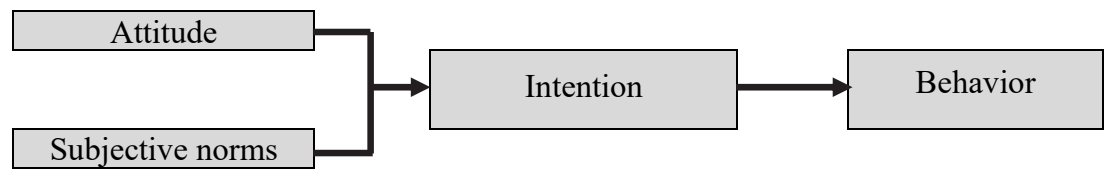

Fig. 1. Ajzen and Fishbein Theory of Reasoned Action (Ajzen, 2011)

\subsection{Entrepreneurship in Cooperative}

Generally, entrepreneurship in cooperatives is defined as a positive mental attitude cooperatively in doing entrepreneurship in order to accept innovative steps and risks and stick with the identity of cooperatives in realizing the needs and welfare. According to Meredith et al. (1982: 5-6), entrepreneurship attitudes of cooperatives involve a person capable of overseeing business opportunities, gathering whatever resources are needed, and taking planned action to achieve success. In other words, a cooperative entrepreneur is a person who has the will to innovate and develop new strategies and have a better cooperative system. From the above theory, there are six aspects that should be considered as follows;

a. Cooperative-entrepreneurs should have a goal to promote cooperative organizations, both cooperative business and member businesses.

b. Every business activity should be carried out cooperatively and considered by the members.

c. Cooperative-entrepreneurs should continue to search for and find any innovation (Drucker, 2007: 150).

d. Cooperative-entrepreneurs should take any risk because sometimes planning is not as expected.

e. Cooperatives-entrepreneurs continue to work with cooperative identities where the needs of members will always be a priority.

f. Cooperative-entrepreneurs must have a goal to achieve the welfare of members.

Kuratko and Hodgetts (2004:30) explained that entrepreneurship was a continuous process of vision, change, and creation. This needs more energy and enthusiasm to build new ideas and creative solutions. Essential materials incorporate an interest to take some risks based on time, equity, or career; ability to formulate an effective business team; creative skills to get the resources required; and some skills of creating a strong business plan; and a vision to learn opportunities where others see chaos, contradictions, and confusion. According to Izedonmi and Okafor (2008), the characteristics of cooperativeentrepreneurship are similar to entrepreneurial characteristics, where entrepreneurs ought to be able to monitor and identify opportunities and seek sources to reach goals. Koh (in Izedonmi and Okafor, 2008) recommends that the characteristics of an entrepreneur are the primary core of entrepreneurial behavior and performances.

Other experts also state the following characteristics of entrepreneurship;

a. Achievement requirements (McClelland, 1987:2011)

b. Locus of control (Rotter, 1966)

c. Risk taking (Brockhaus, 1980)

d. Proactive (Crant, 2000)

e. Tolerance to the unexpected (Bateman \& Grant, 1993)

f. Creativity (Drucker, 2007)

Furthermore, Meredith et al. (1982: 38-39) argues that the characteristics of entrepreneurs are self-confidence, task and outcome oriented, risk-taking, leadership, originality, and future-oriented. These traits show that the only thing entrepreneurs need is creativity that is not the innate ability of something they have learned. Therefore, entrepreneurs need to explore and learn creativity so that every entrepreneur will have his/her own characteristics, while entrepreneurship is an attitude that comes from creative and innovative entrepreneurs.

Lambing and Kuehl (2006:16) state the four basic elements of a successful entrepreneur;
a. Ability (IQ and skill)
b. Courage (EQ and mental)
c. Consistency (self-motivation)
d. Creativity (experience)

In addition, Kuratko (2016) describes that the characteristics of entrepreneurship are commitment, determination, consistency, opportunity-oriented, imitative, responsible, internal locus control, integrity, creative, independent, confident, optimistic and team building, while Barringer and Ireland (2012: 10) describe four characteristics of successful entrepreneurs;

a. Passion for doing business

b. Focus on products and customers 
c. Consistency even if it fails

d. Skills

The cooperative is a business unit engaged in the economy to promote economic growth through increased productivity and revenues. According to Atkinson and Howard (2008:7) the productivity of an economy can grow in two different ways. First, productivity can be increased by increasing the value of goods and services produced (e.g. shifting production from standard commodities based on existing technology to new, higher performance technologies where consumers are willing to pay premiums and also gain greater economic benefits). Second, productivity can grow by generating a series of certain goods or services more technically efficiently. Ropke (1995) states that productivity gains can be recovered in two ways; first, innovative activities (e.g., use of productive technology); secondly, increased work activity (eg, creating new facilities). Meanwhile, Drucker (1985) states that entrepreneurship is the ability to create new offerings. Zimmerer and Scarboroug (2008: 5) state entrepreneurship is the process of implementation and finds opportunity to have a better life.

McClelland (1987:2011) shows the relationship between entrepreneurship levels and attitudes as follows;

a. Take risks at a moderate level

The attitudes of entrepreneurs, who have a high value attainment, are the most likely means of achievement, albeit at a moderate level.

b. Have responsibility

Entrepreneurs continue to think that each task has its own values; so, an entrepreneur really knows how to be responsible in working together and decides whatever he does.

c. Know the consequences

Entrepreneurs learn from mistakes and experiences, but also monitor and accept the expected and unexpected. So an entrepreneur knows the consequences of certain tasks.

d. Ability to design and organize long-term planning.

Entrepreneurs must plan any strategy to achieve high-achievement in the future. Entrepreneurs will continue to manage time, opportunities, strategies effectively and efficiently.

\section{Theoretical framework}

The key to the success of a cooperative is characterized by the high level of participation of its members. In order for members of the cooperative to participate actively, the members must have high motivation to work together. For that, the motivation of members of the cooperative is very important to be maintained and improved so that members remain willing to join the cooperative. The more members join the cooperative, the more economic and social benefits are gained. A good cooperative organization should recruit managers with professional attitude in managing cooperatives according to their vision and mission.

A developing cooperative should have a manager who has a good entrepreneurship attitude, because this attitude leads to the success of the cooperative. The entrepreneurship attitude of a good manager at a cooperative will increase members' participation, and this is the key to the success of the cooperative. A rapidly growing cooperative must have a manager who has the attitude of a good entrepreneur, because this attitude leads to the success of the cooperative. The entrepreneurship attitude of a good manager at a cooperative will increase member participation, and this is the key to the success of the cooperative. Fig. 2 illustrates the theoretical framework used.

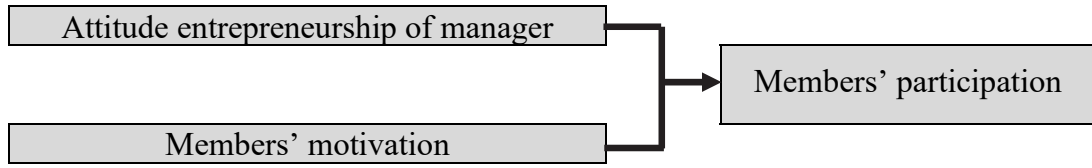

Fig. 2. Theoritical Framework

In this study, Meredith's theory (Meredith et al., 1982: 68) is used to describe the entrepreneurship attitude of managers as independent variables seen from several indicators, namely; 1) knowing priorities, 2) taking risks, 3) innovation, 4) attitudes toward duty, 5) respecting time, 6) achievement motivation, 7) confidence and 8) responsibility. This attitude is owned by the manager individually and influences the style and behavior of his work in managing the cooperative. The influence of the entrepreneurial attitude of cooperative managers that increase member participation as a dependent variable is the key to successful cooperatives, emphasized in this theory.

Hypothesis:

1. The entrepreneurial attitude of the cooperative manager has a significant effect in increasing member participation.

2. The motivation of cooperative members has a significant effect in increasing member participation.

3. The entrepreneurial leadership / managerial attitude of the members and the motivation of members have a significant effect in increasing member participation in the Province of North Sumatera. 


\section{Methodology}

This research is accomplished by using quantitative research method and starting from April to July 2017. The population in this study covers all active cooperatives in North Sumatera Province, Indonesia. Of all the existing cooperative populations, a deliberately selected hundred cooperative units were willing to participate in this study, and from each cooperative a manager or leader, and a member of each cooperative were selected. So, overall there are a hundred people managers and a hundred members as respondent respectively. The research instrument is a questionnaire with Likert scale 1.5. Data were analyzed by using correlation analysis and multiple regression analysis. Then, the description of the variables and indicators is as stated in Table 1 below.

Table 1

The Description of Variables and Indicators

\begin{tabular}{|c|c|c|c|c|}
\hline Variables & Sub Variables & Dimension & $\begin{array}{l}\text { Indicators } \\
\end{array}$ & Code \\
\hline \multirow{20}{*}{$\begin{array}{l}\text { Entrepreneur-ship } \\
\text { attitudes of } \\
\text { manager } \\
\text { (Meredith's } \\
\text { Theory) }\end{array}$} & \multirow[t]{3}{*}{ Knowing Priorities } & $\begin{array}{l}\text { The importance of } \\
\text { informations }\end{array}$ & $\begin{array}{l}\text { Keep updating information in decision making of } \\
\text { bussiness opportunity }\end{array}$ & EA1 \\
\hline & & Availability of funds & Importance of available fund as capital & EA2 \\
\hline & & The benefit of credit & The importance of having credit & EA3 \\
\hline & \multirow[t]{2}{*}{ Taking any risks } & Chance of success & Invest againts big chance of achievement & EA4 \\
\hline & & The risk of using credit & Courage to propose the credit & EA5 \\
\hline & \multirow{2}{*}{ Innovation } & Seeking for new idea & Desire to seek for new ideas & EA6 \\
\hline & & Creating new product & Desire to create a new products & EA7 \\
\hline & \multirow[t]{2}{*}{ Attitude againts task } & Stay optimistic & Believe that business will be successful & EA8 \\
\hline & & Struggling & Learn from the failure & EA9 \\
\hline & \multirow[t]{3}{*}{ Apreciating the time } & Time is capital & Spending spare time to learn & EA10 \\
\hline & & High quality bussiness & Keep increasing the quality of bussiness & EA11 \\
\hline & & On time & Keeping promises to the clients & EA12 \\
\hline & \multirow{2}{*}{$\begin{array}{l}\text { Achievement } \\
\text { motivation }\end{array}$} & Desire to be successful & Work motivation is reach the achievement & EA13 \\
\hline & & Fighthing & Keep learning from the failure & EA14 \\
\hline & \multirow[t]{3}{*}{ Confidence } & Undoubt & Never doubt to do an action & EA15 \\
\hline & & Stay optimistics & Stay optimistics in any situation & EA16 \\
\hline & & & Knowing the weakness & EA17 \\
\hline & \multirow{3}{*}{ Responsibi-lity } & All out & Finishing the task well & EA18 \\
\hline & & Learning of mistakes & Learning the previous mistakes & EA19 \\
\hline & & Increasing the quality & Responsible for any tasks & EA20 \\
\hline \multirow{7}{*}{$\begin{array}{l}\text { Member } \\
\text { motivation }((\mathrm{N}- \\
\text { Ach Theory) }\end{array}$} & \multirow{4}{*}{$\begin{array}{c}\text { Need for } \\
\text { achievement }\end{array}$} & Increase the capital & Can borrow in cooperatives & MM1 \\
\hline & & Meet the needs of a family & $\begin{array}{c}\text { Can shopping meet the needs of a family in } \\
\text { cooperatives }\end{array}$ & MM2 \\
\hline & & Having saving & Have collected savings can get any time & MM3 \\
\hline & & Can borrow money & Can borrow money if needed & MM4 \\
\hline & \multirow[t]{2}{*}{ Need for power } & \multirow[t]{2}{*}{ A chance to be committee } & Can become managers & MM5 \\
\hline & & & Can become employee & MM6 \\
\hline & Need for affiliation & $\begin{array}{l}\text { Has many friends } \\
\text { Sharing of experience } \\
\text { Working in teamwork }\end{array}$ & $\begin{array}{l}\text { More friend colleague having } \\
\text { The sharing of experience among member colleague } \\
\text { Can work together with other member }\end{array}$ & $\begin{array}{l}\text { MM7 } \\
\text { MM8 } \\
\text { MM9 }\end{array}$ \\
\hline \multirow{13}{*}{$\begin{array}{l}\text { Member } \\
\text { Participation } \\
\text { (Ropke, 2003) }\end{array}$} & \multirow[t]{4}{*}{ Decision making } & Attendance & Attend the meetings & MP1 \\
\hline & & Acitvity & Active in giving ideas & MP2 \\
\hline & & & Active in finding the erros & MP3 \\
\hline & & & Active in giving suggestions & MP4 \\
\hline & \multirow[t]{2}{*}{ Capital contribution } & Payment in time & Pay principal and mandatory savings & MP5 \\
\hline & & Saving the donation & Having voluntary saving & MP6 \\
\hline & \multirow[t]{4}{*}{ Benefit the profit } & Total of rest income & Profit rest & MP7 \\
\hline & & Transaction & Doing transaction actively & MP8 \\
\hline & & & Desire to use loan service & MP9 \\
\hline & & The using of credit & Desire to use credit service & MP10 \\
\hline & \multirow{3}{*}{$\begin{array}{l}\text { Monitoring } \\
\text { involvement }\end{array}$} & Visiting & The intensity of visiting & MP11 \\
\hline & & Giving critics and & Giving critics actively & MP12 \\
\hline & & suggestions & Giving suggestion actively & MP13 \\
\hline
\end{tabular}

\section{Results}

First, an internal consistency analysis has been performed to test the validity and reliability of the instruments used. Nunnally (1978) suggested an acceptable alpha value is a minimum scale of 0.6. As shown in Table 2, the alpha value obtained from the reliability analysis for this study is greater than 0.5 . This analysis involved as many as 100 respondents as manager or leader and 100 members of the cooperative. Managers have responded to the independent variables of entrepreneurship attitudes, while cooperative members have responded to independent variables of member motivation and dependent variables i.e. participation of cooperative members. In Table 2 it can be concluded that this instrument has good internal consistency and is also reliable due to the Cronbach value $\alpha>0.6$. From the validity test results it can be concluded that all items are valid because all Corrected Item Total Correlation is positive. 
Cronbach alpha value calculated for determining the reliability of the survey. First, according Hair et al. (2007), the reliability level of the Cronbach's Alpha value is as follows:

$0.00-0.20$ : the scale is less reliable

$>0.20-0.40$ : the scale is rather reliable

$>0.40-0.60$ : the scale is quite reliable
$>0.60-0.80:$ the scale is reliable

$>0.80-1.00$ : the scale is very reliable

Table 2

Reliability Analysis Result

\begin{tabular}{lll}
\hline Variables & Number of Item & Cronbach's Alpha \\
\hline Entrepreneurship attitude of managers (EA) & 20 & 0.729 \\
Members motivation (MM) (MM) & 9 & 0.602 \\
Members participation (MP) & 13 & 0.575 \\
\hline
\end{tabular}

Secondly, a classical assumption test has been performed using Kolmogorov-Smirnov test and multicolinearity test results as in Table 3. Kolmogorov-Smirnov test is performed by comparing the distribution of data to be tested for normality with the standard normal distribution that has been converted to Z-Score form, and if the significance level is $>0.05$ then the sample comes from a normally distributed population. As shown in Table 3, Asymp.Sig (2-tail) is greater than 0.05 for each variable. Thus, it can be concluded that the data is normally distributed. Next, multicollinearity test using Variance Inflation Factor (VIF) and Tolerance, where data is feasible if tolerance values $>0.10$ and VIF $<10$. As Table 3 shows, the tolerance values obtained are more than $0.10, \mathrm{VIF}<10$ for all variables.

Table 3

Classical Assumption Test Result

\begin{tabular}{lccll}
\hline Variables & KS- Z & asymp.sig & Collinearity Stat. \\
\hline EA & 1.485 & 0.024 & Tolerance & 0.223 \\
MM & 1.682 & 0.007 & 0.223 & 4.479 \\
MP & 1.874 & 0.002 & - & 4.479 \\
\hline
\end{tabular}

The result of the heteroscedasticity test shows random residual plot, not describing a particular form such as wavy, wide or narrow, so it can be concluded that the linear regression model of this study is not heteroscedasticity, as shown in Figs. (3-5). Thus, it can be concluded that the data has met the requirements in the classical assumption test. From Fig. 5 it can be seen that the plots are spread evenly above and below the horizontal line, and the horizontal line is right in the middle of the diagram. The picture above clearly shows that all plots remain random. The picture shows no wave, wide and narrow patterns. It is therefore assumed that the data is distributed normally.

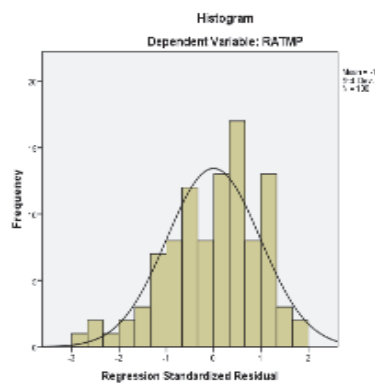

Fig. 3. Histogram Data Pattern

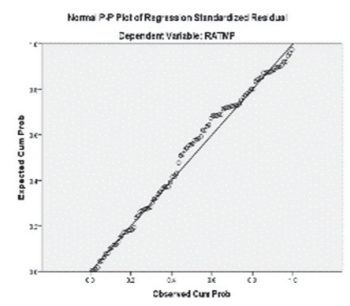

Fig. 4. Normal Probability Plot

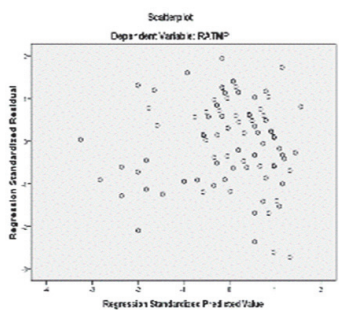

Fig. 5. Detrend QQ Plots

Third, Pearson correlation test was performed. From the Pearson correlation coefficient analysis, there is a correlation between the variables as presented in Table 4, where the correlation coefficient was found to be positive and statistically significant at the $0.01(\mathrm{p}<0.01)$ sig. level. 2-tailed. This means that member participation is significantly correlated with the entrepreneurship attitude of cooperative managers and member motivations, with $r_{1}=0.866^{* *}$ and $r_{2}=0.902^{* *}$ respectively. Similarly there is a significant relationship between the entrepreneurship attitude of cooperative managers with motivation members, amounted to $r_{3}=0.881^{* *}$.

\section{Table 4}

Pearson Correlation Coefficients

\begin{tabular}{lccc}
\hline Variables & MP & EA & MM \\
\hline MP & 1.000 & & \\
EA & $0.866^{* *}$ & 1.000 & 1.000 \\
MM & $0.902^{* *}$ & $0.881^{* *}$ & \\
\hline
\end{tabular}


** Correlation is significant at the 0.01 level (2-tailed)

* Correlation is significant at the 0.05 level (2-tailed)

Fourth, multiple linear regression analysis has been performed. From Table 5, the value of $\mathrm{R}^{2}$ is 0.836 , which means that $83.6 \%$ of the independent variables (entrepreneurship attitude of manager and member motivation) influence the dependent variable, while the remaining $16.4 \%$ is influenced by other variables. The $\mathrm{F}$ value of $247,430^{* *}, \alpha<1 \%$, means that the independent variables (i.e. the entrepreneurship attitude of the cooperative manager and member motivation) simultaneously and very significantly increase the members participation of cooperative which is the key to the success of the cooperative in North Sumatera Province.

Table 5

Summary of Regression Analysis

\begin{tabular}{llll}
\hline Variable & Beta & t-value & Sig.(2-tailed) \\
\hline Constant & 0.589 & 4.097 & 0.000 \\
EA & 0.293 & $3.667^{* *}$ & 0.000 \\
MM & 0.549 & $7.136^{* *}$ & 0.000 \\
\hline $\mathrm{R}^{2}$ & 0.836 & & \\
Adjust. R & & \\
F-Test & 0.833 & & \\
Sig.(2-tailed) & 247.430 & & \\
\hline
\end{tabular}

From the table above, the model of regression equation obtained is as follows;

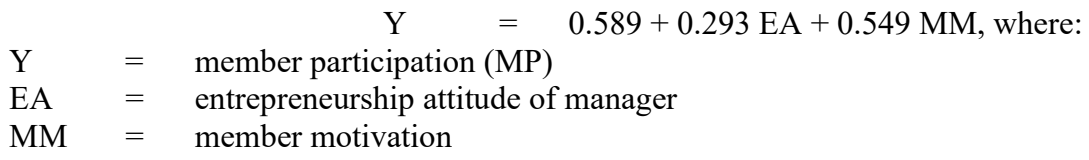

\section{Discussion}

As we can observe from the first hyphothesis, entrepreneurship attitude of manager and motivation of cooperative member have real effects in increasing cooperative member participation in North Sumatera Province, Indonesia. Similarly, partially entrepreneurship attitude of cooperative managers and cooperative member motivation significantly increase the participation of cooperative member in North Sumatera Province, Indonesia. These are attitudes of managers in entrepreneurship, especially driven by a high sense of responsibility for the task and the belief for success, and the attitude that respects the time, and care about the importance of information. Another encouraging attitude is the importance of new innovations and eager to succeed. Attitudes that need to be improved again is the attitude of courage in taking the risk of courage owe or proposed credit and give attention to the fund as a cooperative capital. According to the second hyphothesis, the motivational factors of cooperative members are driven by cooperation with other members in a working team and the fulfillment of family needs in shopping at cooperative stores as well as access to borrow on cooperatives. Attitudes that need to be improved again is the motivation of members in sharing experiences among members and the opportunity to become employees. Member participation factors are driven primarily by the high involvement of members in the decision making process of cooperative members' attendance in meetings held by cooperatives and the benefits of member benefits such as credit usage, and obtaining some shared profits. Attitudes that need to be improved again is the liveliness of members in giving suggestions or ideas and advices in advancing cooperatives. Participation of a person in a particular community must experience self-involvement and ego involvement. In other words, if a person participates in a particular community, then he/she should involve his/her thoughts, emotions, and feelings. Participation of members of the cooperative in this study is encouraged because of the high involvement of members in the decision-making process which is shown from the presence of cooperative members in the meetings held by the cooperative, and the benefit of benefits obtained by members such as the use of credit, and get a share of profit or residual results.

\section{Conclusion}

After analyzing the data, the conclusions are drawn as follows;

The results of this study have indicated that cooperative entrepreneurship attitude is a problem that has been owned by managers to manage and members of cooperatives in running efforts at cooperative companies. The lessons given in cooperative education for all managers and members should also instill entrepreneurship attitudes and cooperative enterprises can continue to grow and sustainably in the future. This is also a suggestion by Rajaei et al. (2011) studying in Zanjan Province, Iran that provides public and specialized training for managers and members of agricultural cooperatives is recommended. There is a significant relationship and influence between the entrepreneurship attitude of managers towards the participation of the members. There is a significant correlation and influence between members' motivation toward member participation as the key of success of cooperative. There is a significant influence and correlation between entrepreneurship attitude of 
managers with the motivation of joint members towards the participation of members as the key to successful cooperatives in North Sumatra, Indonesia.

\section{Suggestion}

The entrepreneurial attitude of the cooperative manager has increased the participation of the members. This attitude is rightly owned by everyone involved in cooperatives, such as employees, boards of directors, even members of the cooperative. A good entrepreneurial attitude will push forward the cooperative business. Entrepreneurship education and training provided by the government through the Ministry of Cooperatives and Small and Medium Enterprises existing in Indonesia should include entrepreneurship education and training so as to motivate members to increase their participation in cooperatives. It has also been suggested by Rajaei et al. (2011) in Zanjan Province, Iran for government to provide entrepreneurship training for public and specifically for managers and members of agricultural cooperatives there. Related to the weakness of entrepreneurship attitude in the case of risk tolerance, courage owed, it should be given training in making good business plan, how much profit and loss obtained, so as to predict the occurrence of risk. Members of the cooperative are trained to seek relevant information that supports their efforts in making decisions quickly and confidently based on careful business planning.

\section{Acknowledgment}

We would like to thank and appreciate to Directorate of Research and Community Service, Directorate General of Research and Development Strengthening, Ministry of Research, Technology and Higher Education of the Republic Indonesia for the Competitive Grant 2016-2017 given to support this research.

\section{References}

Acs, Z. J., \& Audretsch, D. B. (2010). Handbook of Entrepreneurship Research. ISBN: 978-0-387-24080-0 (Print) 978-0387-24519-5 (Online).

Ahmed, A., \& McQuaid, R. W. (2005). Entrepreneurship, management, and sustainable development. World Review of Entrepreneurship, Management and Sustainable Development, 1(1), 6-30.

Ajzen, I., \& Fishbein, M. (1980). Understanding attitudes and predicting social behavior. Englewood Cliffs, NJ: PrenticeHall. 278p.

Ajzen, I. (2011). The theory of planned behaviour: Reactions and reflections. Psychology \& Health, 26(9), $1113-1127$.

Allport, G. W. (1945). The psychology of participation. Harvard University. The Psychological Review, 3, $117-132$.

Andersson, M., \& Noseleit, F. (2011). Start-ups and employment dynamics within and across sectors. Small Business Economics, 36(4), 461-483.

Atkinson, R.D., \& Howard, W. (2008). Boosting productivity, innovation, and growth through a national innovation foundation. Brookings-ITIF. The Information Technology and Innovation Foundation. 67p. https://scienceprogress.org/

Barringer, B. R., \& Ireland, R. D. (2012). Entrepreneurship: Successfully launching new ventures, $5^{\text {th }}$ ed., Pearson Education Inc.

Bateman, T. S., \& Crant, J. M. (1993). The proactive component of organizational behavior: A measure and correlates. Journal of Organizational Behavior, 14(2), 103-118.

Brockhaus Sr, R. H. (1980). Risk taking propensity of entrepreneurs. Academy of management Journal, 23(3), 509-520.

Calhoun, F. J., \& Joan, R. A. (1995). Readings, cases, and study guide for Psychology of adjustment and human relationships. $3^{\text {rd }}$ ed. New York: McGraw-Hill Publishing Company. 512p.

Chareonwongsak, K. (2017). Enhancing board motivation for competitive performance of Thailand's co-operatives. Journal of Co-operative Organization and Management. http://dx.doi.org/10.1016/j.jcom.2017.01.001

Crant, J. M. (2000). Proactive behavior in organizations. Journal of Management, 26(3), 435-462.

Drucker, P.F. (1998). The discipline of innovation. Harvard Business Review. November-December, pp. 3-8. DOI 10.1007/978-3-642-28675-9_1.

Drucker, P.F. (2007). Innovation and Entrepreneurship, Practice and Principles. (Rev.ed). Amsterdam, London: ButterworthHeinemann.

Ernita, F. (2015). Performance measurement using Balanced Scorecard concept on co-operatives: implication in Indonesia. Balance (Million IDR), 8, 14-898.

Ernita, F., \& Al Rozi, A. (2014a). Factors affecting the members participation on cooperative in north Sumatera. International Journal of Scientific \& Technology Research, 3(10), 113-117.

Ernita, F., \& Al Rozi, A. (2014b). The influence of motivations and quality of service on member participation of cooperative in North Sumatera. Proceeding, The 3rd International Conference on Multidisciplinary Research, p.57-62, ISBN:978602-18851-9-2.

Ernita, M.P., Ghani, A., Firmansyah, M.S., Jusoh, M.S., \& Amlus, M.H. (2016). The effect of member participation on leadership and organizational culture towards cooperative performance: A Balanced Scorecard Concept. Australian Journal of Basic and Applied Sciences, 10(6), 69-76. 
Fotoohi, M. (2014). Entrepreneurial cooperative development strategies. Kuwait Chapter of Arabian Jurnal Bisnis dan Manajemen Ulasan, 3(10), 270-278.

Kuratko, D. F. (2016). Entrepreneurship: Theory, process, and practice. Cengage Learning.

Hair, J.F., Black, W.C., Babin, B.J., \& Anderson, R.E. (2010). Multivariate Data Analysis, $7^{\text {th }}$ ed., Prentice Hall, Upper Saddle River, New Jersey.

Hanel, A. (2005). Cooperative Organization Principal Thoughts on the Organization of Cooperation and Development Policy in Developing countries. Graha Science. Yogyakarta.

Harun, M. Z. M. B., \& Mahmood, R. B. (2012). The relationship between group cohesiveness and performance: An empirical study of cooperatives movement in Malaysia. International Journal of Cooperative Studies, 1(1), 15-20.

Hadayati, N., Rifki, H., \& Pradesa, H. A. (2016). The Influence of Service Quality and Sense of Belonging Toward Members' Participation in Co-operative Enterprise. Journal of Business and Management (IOSR-JBM), 18, 55-65.

Izedonmi, P. F., \& Moses, C. (2008). Assessment of the entrepreneurial characteristics and intentions among academics. Ife Psychologia, 16(2), 153-168.

Kuratko, D. F., \& Hodgetts, R. M. (2004). Entrepreneurship: Theory, Process Practice. Mason, Ohio: Thomson South Western.

Lambing, P. A., Kuehl, C. R. (Apr, 2006). Entrepreneurship (4 ${ }^{\text {th }}$ Edition). Prentice Hall. 336p. ISBN 13: 9780132281744

Levi, Y., \& Pellegrin-Rescia, M. L. (1997). A new look at the embeddedness/disembeddedness issue: cooperatives as terms of reference. The Journal of Socio-Economics, 26(2), 159-179.

Mahazril'Aini, Y., Hafizah, H. A. K., \& Zuraini, Y. (2012). Factors affecting cooperatives’ performance in relation to strategic planning and members' participation. Procedia-Social and Behavioral Sciences, 65, 100-105.

McClelland, D. C. (1987; 2011). Characteristics of succesful entrepreneurs. Journal of Creative Behaviour, $21(3), 219-233$.

Meredith, G. G., Robert, E. N., \& Philip, A. N. (1982). The practice of entrepreneurship. Geneva, International Labour Office, 196 p. ISBN: 9789221028390.

Ministry of Cooperation and SME of the Republic of Indonesia (2015). http://www.depkop.go.id/pdfviewer/?p=uploads/tx_rtgfiles/1F_Koperasi_Desember_2015.pdf

Münkner, H.H. (2013). Worldwide regulation of co-operative societies - an Ōverview. Working Paper n. 53 | 13. ISSN 22818235. 30p.

Nunnally, J. C. (1978). Psychometric Theory. McGraw-Hill.

Rajaei, Y., Yaghoubi, J., \& Donyaei, H. (2011). Assessing effective factors in development of entrepreneurship in agricultural cooperatives of Zanjan province. Procedia-Social and Behavioral Sciences, 15, 1521-1525.

Regts, N. (2009). The impact of knowledge and participation on cooperative loyalty in Uganda and Tanzania. Does certification matter? Nijmegen: Radboud University. Master thesis.

Riswan, R., Suyono, E., \& Mafudi, M. (2017). Revitalization model for village unit cooperative in Indonesia. European Research Studies, 20(4A), 102-123.

Ropke, J. (2003). The Economic Theory of Cooperative Enterprises in Developing Countries with Special Reference to Indonesia. Philip Marburg, University of Marburg.

Rotter, J. B. (1966). Generalized expectancies for internal versus external control of reinforcement. Psychological Monographs: General and Applied, 80(1), p.1-28.

Verhees, F.J.H.M., Sergaki, P., \& Dijk, van G. (2015). Building up active membership in cooperatives. New Medit, 14(1), 4252.

Taiwo, A. O. (2011). Effect of members participation on cooperative performance: A study of selected multipurpose cooperative societies (MCS) in Awka South Lga of Anambrastate, Nigeria. International Journal of Multi-Disciplinary Research. 4, 117-126.

Zimmerer, T. W., \& Scarboroug, N. M. (2008). Essentials of entrepreneurship and small business management. PrenticeHall.

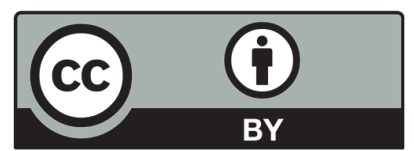

(C) 2020 by the authors; licensee Growing Science, Canada. This is an open access article distributed under the terms and conditions of the Creative Commons Attribution (CC-BY) license (http://creativecommons.org/licenses/by/4.0/). 